\title{
Screening of germplasm of pigeonpea against phytophthora stem blight
}

\author{
L.B. YADAV*, K.P.S. KUSHWAHA AND R.P. MAURYA
}

Department of Plant Pathology, College of Agriculture ,G.B. Pant University of Agriculture and Technology, Pantnagar, U.S. NAGAR (UTTARAKHAND) INDIA

\section{ARITCLE INFO}

Received : 21.01.2015

Revised : 13.02 .2016

Accepted : 27.02.2016

\section{KEY WORDS :}

Germplasm, Phytophthora drechsleri f. sp. cajani, Pigeonpea, Registance, Susceptible

*Corresponding author:

Email: lalbahadurpatho@gmail.com

\begin{abstract}
Pigeonpea [Cajanus cajan (L.) Millsp.] is very important and old pulse crop, which is used in various ways. Its main use is in the form of Dal (split seed) in the Indian diet. The phytophthora stem blight caused by Phytophthora drechsleri f.sp. cajani is the third potentially important disease of pigeonpea crop after wilt and sterility mosaic wherever crop is grown during Kharif season mostly in northern parts of India. The present investigation was undertaken with an objective to develop disease resistant material by screening of pigeonpea germplasm against phytophthora stem bight. A screening trail was conducted by employing fourty pigeonpea germplasms, in which Only one germplasm namely ERG-65 was found resistant, however, 27 germplasms included HY-3C, KPL44, MA-06, Vipula 42, WRP-1, Pusa-992, BDN-711, RVSA-07-22, AL-1593, RVSA-07-10, GAUT-001, BSMR-853, BSMR-2, JICM-189, BSMR-579, BSMR571, RVKT-260, KPL-43, AL-1798, RVKT-261, CORG-9701, GT-101, BRG-2, AKT-8811, RVSA-7-29, ICPL-8863, and ICPL-87119 were found moderately resistant. Resistant germplasm namely ERG-65 may be utilized as a resistant donor in developing resistant variety against the phytophthora stem blight.
\end{abstract}

How to view point the article : Yadav, L.B., Kushwaha, K.P.S. and Maurya, R.P. (2016). Screening of germplasm of pigeonpea against phytophthora stem blight. Internat. J. Plant Protec., 9(1) : 120-123. 